\title{
PERCEPTIONS OF KNOWLEDGE MANAGEMENT AND INTELLECTUAL CAPITAL IN THE BANKING INDUSTRY
}

\author{
Carla Curado \\ Management Department - ISEG \\ - Economics and Business Management School - \\ Technical University of Lisbon \\ Rua Miguel Lupi, 20 \\ 1249-078 Lisbon \\ PORTUGAL \\ Phone: (+351) 213925965 \\ Fax: (+351) 213922808 \\ E-mail: ccurado@,iseg.utl.pt
}

\begin{abstract}
The purpose of this article is to capture the perceptions of knowledge management and intellectual capital in the banking industry. The reason for developing such a study is that little research as clearly addressed both subjects at the same time. After verifying that knowledge management and intellectual capital are identified as different concepts in the banking industry, the final aim of the author is to identify the relevancy and perceived value of such organizational variables in the banks. In that sense, this research paper follows a qualitative approach and considers two different knowledge management strategies: exploitation and exploration and three different intellectual capital components: human capital, internal structures and external structures. The paper develops and analyses several interviews in the banking industry at top management level across different banks. This study led to some interesting findings, allowing to empirically verify most of the theoretical knowledge management and intellectual capital literatures, as well as to gather some examples of its routines and elements, and also to identify the value given to knowledge management and intellectual capital by the banks that took part of the study. There are some research limitations regarding the industry context, but this may result in a stimulus for the replication of the work in other industries. The originality of the paper regards the way it addresses simultaneously knowledge management and intellectual capital, such related concepts.
\end{abstract}

\section{RESEARCH ARTICLE}

KEY-WORDS: Exploration, Exploitation, knowledge management, intellectual capital, banking industry, Portugal. 


\section{Knowledge management}

Knowledge management is an organizational discipline bridging information demand and supply in support of learning processes within organizations (Huizing and Bouman, 2002). Knowledge will be the foundation of success in the $21^{\text {st }}$ century (Wiig, 1997). Knowledge is a puzzling concept, tough to measure (Spender, 2002). Value is created when stocks of knowledge are employed and degrades when they remain unused (Pike et al., 2002). Knowledge assets are not consumed when they are applied to solving organizations problems, on the contrary, a knowledge asset's value is generally maintained and often enlarged by its application, while conventional assets must be depreciated or replaced (Spender, 2002). Thus, knowledge management is a strategic issue (Nonaka and Konno, 1998; Alvarez and Barney, 2001; Bontis and Nikitopoulos, 2001).

The knowledge-based approach opens up new questions about the interaction of the explicit and tacit (Polanyi, 1962) knowledge assets (Spender, 2002). This new organizational reality challenges the traditional planning, organizing, leadership, controlling, accounting and other organizational practices (Sveiby, 1997), (Guthrie, 2001), (Mouritsen et al., 2001). Firms need to redefine their strategies and functions to compete in the knowledge era. The "knowledge intensive firms" represent the new kind of organizations that employ large proportion of highly qualified staff (the "knowledge workers" - Drucker, 1993) (Blackler, 2002). The knowledge-based competitive advantage (Nonaka, 1991; McEvily and Chakravarthy, 2002) is sustainable because the more a firm already knows, the more it can learn ("absorptive capacity" - Cohen and Levinthal, 1990). Knowledge management gathers its creation and transfer (Sveiby, 1996; Nonaka et al., 2000b; Buckley and Carter, 2000; Choo, 2002; Zack, 2002).

Following the words by Nonaka (1991) “... the only true lasting competitive advantage is knowledge..." it is possible to find some related concepts like the knowledge-based organization (Blackler, 2002) and the knowledge-based advantage (McEvily and Chakravarthy, 2002). These authors recognize that non-observable factors have impact on firm performance. Those factors, as management capabilities and competences, technical knowledge or tacit organizational routines, may turn out to be the main determinants of firm performance (Dess et al., 1995).

The tacit, specific and complex knowledge that the organization develops inside generates long lasting advantages because that knowledge is difficult to imitate (McEvily and Chakravarthy, 2002). The firm absorbs internal and external knowledge, combines them with pre-acquired knowledge, and creates new one (Cohen and Levinthal, 1990). The organization may enlarge its knowledge base through the new application of pre-existing knowledge in the firm (Szulanski, 2003), as these new combinations of pre-existing knowledge generate new knowledge (Gratton and Ghoshal, 2003). Even external, explicit knowledge, involving high acquisition costs to the firm and available to competitors simultaneously, combined with unique internal knowledge may result in new and exclusive knowledge (Zack, 2002).

Literature presents a distinction between two main knowledge management strategies: exploitation and exploration (March, 1991; Lovas and Ghoshal, 2000; SubbaNarasimha, 2001; Choo and Bontis, 2002; Bierly and Daly, 2002; Ichijo, 2002; Knott, 2002; Zack, 2002), these will be the ones considered in this study. This typology has been followed by a large number of authors, it presents a considerable cumulative literature and it has already been operationalized. The exploitation knowledge management strategy values the transfer and the diffusion of knowledge within the organization; on the contrary, the 
exploration knowledge management strategy promotes innovation and the creation of new knowledge.

\section{Intellectual capital}

The intellectual capital concept emerged from the differences found between market and book values (Sveiby, 1997; Brooking, 1997; Bontis, 1998; Edvinsson, 2000; Joia, 2000; Bontis, 2002a; Bontis, 2002b; Pike et al., 2002), and it represents the wealth of ideas and ability to innovate that will determine the future of the organization (Bontis, 2002a). The intellectual capital of the firm is such a powerful resource (Barney, 1991; Alvarez and Busenitz, 2001; Cohen and Prusak 2001; SubbaNarasimha, 2001; Bontis, 2002c; Nahapiet and Ghoshal, 2002) that it is often recognized as the most valuable one (Stewart, 1997; Cohen and Prusak, 2001; Nahapiet and Ghoshal, 2002), and it is the most important asset in the organization (Wiig, 1997).

Intellectual capital is an intangible asset (Sveiby, 1997; Canibano et al., 1999; Stewart, 1998; Sánchez et al., 2000; Caddy et al., 2001; Sveiby, 2001; Winter and Szulanski, 2002) and it can be seen as the basis of competitive advantage (Birchall and Tovstiga, 1999; Davenport and Prusak, 2000).

Bontis et al. (2002) suggest that intellectual capital represents the "stock" of knowledge that exists in an organization. Intellectual capital relates to all organizational knowledge; tacit and explicit; individual and collective (De Carolis, 2002). Managing this stock of knowledge in the firm is the domain of the knowledge management (Choo and Bontis, 2002). Stocks are the amounts of the components at certain point in time, and flows are the permanent conversions of intellectual capital that take place between any of its forms. This perspective that considers the existence of stocks and flows of intellectual capital is relevant for the Resource-Based View of the firm (Ariely, 2003). According to Dierickx and Cool (1989), the resources are stocks that do not adjust instantaneously, but are accumulated through consistent investments.

Intellectual capital is such a different resource from the traditional ones, as land, labour or financial capital. Contrary to those, intellectual capital returns may increase at increasing rates, if the knowledge management used allows it (Teece, 1998; Zack, 2002; Garud and Kumaraswamy, 2002). The technological and organizational systems may help knowledge management to achieve that (Garud and Kumaraswamy, 2002). There is a variety of typologies proposed and followed by different authors; however the author will follow the one considering the dimensions (Sveivy, 1997): people, internal structure and external structure, corresponding to: human capital, structural capital and relational capital, as adopted by many authors (Petrash, 1996; Saint-Onge, 1996; Bontis, 1998; Lynn, 1998; Sánchez et al., 2000; Bart, 2001; Bontis et al, 2002; McElroy, 2002; Wexler, 2002).

People or Human capital is, in a simplified way, the knowledge, generally in its tacit form, that employees carry home with them at the end of the day's work, this means, it is the amount of knowledge that doesn't remain in the organization when the individuals go out. Structural capital consists, briefly, of the stock of knowledge that stays in the organization at the end of the day, when the employees go home, this means, it is the tacit and explicit knowledge that is contained in documents, routines and organizational culture, which remains in the organization after the individuals have left. Relational capital is the one involved in the net of the organization's external relationships. This intellectual capital's component is mainly tacit and it is embedded in the long term 
relations established with clients, suppliers, authorities and other institutions (Sánchez et al., 2000).

\section{Metodology}

Managing service firms is different from managing other firms (Bowen and Ford, 2002). Knowledge is the key element in competitive differentiation, even more relevant than money, especially in the service industry, like banks, consulters or information technology providers (Gratton and Ghoshal, 2003). Research took place in the service sector because of the relevancy knowledge management and intellectual capital take place in the sector (Stewart, 1998; Starbuck, 2002).

We approached the research questions at the organizational level within a single industry as advised (Dess et al., 1990; Rouse and Daellenbach, 1999; Hitt et al, 2001) and adopted by many authors (Bontis, 1998; Bontis and Fitz-enz, 2002; Stovel and Bontis, 2002; O'Regan et al., 2002; Hitt et al., 2001; Rouse and Daellenbach, 1999; Bontis et al., 2002; McEvily and Chakravarthy, 2002). The banking sector was chosen following other studies involving the same topics (Mehra, 1996; Saint-Onge, 1996; Bontis et al., 2002; Bontis and Fitz-enz, 2002; Crossan and Hulland, 2002; Stovel and Bontis, 2002; Roberts and Amit, 2003), using semi-structured interviews at the banks (Bontis and Fitz-enz, 2002; O'Regan et al., 2002; Stovel and Bontis, 2002; Hooff et al., 2003).

We approached the research questions (what is the organization's perception of knowledge management? what is the organization's perception of intellectual capital?) at the organizational level within the banking industry. This qualitative study was based upon documental and interviews' content analysis and involved semi-structured interviews that were conducted in 9 out of the 11 banking groups with over 50 branches operating in Portugal. Large banking groups were chosen in order to address institutions that have a national dimension, and not small regional banks, taking into account the country's size, economic context and the national banking industry structure. Interviewees (top managers) from the direction level were chosen because knowledge management is a subject of intense strategic interest.

The information the author gathered in the interviews supported a qualitative approach on knowledge management and intellectual capital in the Portuguese banking industry. The interviews were conducted at the HR direction level, one per bank, because intellectual capital and knowledge transfer at the organizations are strategic domain issues (Szulanski, 2003). The use of interviews allowed us to obtain a qualitative image of the organization in terms of how knowledge is managed (Hooff et.al., 2003).

The author used only HR direction level respondents in order to reduce information and motivation bias effects associated to different hierarchical levels (Hambrick, 1981; Ireland et al., 1987, apub, Doty et al., 1993), as well as functional differences (Dearborn and Simon, 1958; Zajac and Wolfe, 1966, apub, Doty et al., 1993). Using a key informant at organization presents several advantages (Glick et al., 1990, apub, Doty et al., 1993), like: higher probability that the respondent is the best element in the organization to give information; reduced variation in the information and motivation bias; higher probability of organizations accept to participate in the study; and, larger number of organizations in the study, due to budget limitations.

All interviews followed the same scrip made out of opened questions and they were recorded on tapes. At the end of the interview each interviewee was asked to fill in two pages regarding her/his perceptions on knowledge management and intellectual capital. 


\section{Data}

Data on the interviews and data on the information collected using the pages filled in by the interviewees is summarized in the next tables.

Take in Table I.

Data on Table I show us that the interviewee was most of the time a man, on average the interviewee was 44 years old and at a HR high-level position in the bank. On average the interviewee was at the current position for 6 years and at the bank for 14 years. There are four banks over a hundred years old, even though some of them are now part of new groups along with other banks (fusions and acquisitions in the recent years in the banking industry in Portugal made it possible). Each interview took on average 55 minutes, not including the time to fill in the two pages regarding her/his perceptions on knowledge management and intellectual capital.

Take in Table II.

Data on Table II show us that the most of the banks do not have a position fully dedicated to knowledge management, nor to the management of the bank's intellectual capital. Regarding the existence of a CKO - Chief Knowledge Officer, none of the banks participating in the study had one. The author found this very disturbing, as some of these banks in Portugal are national branches of international well-known prestigious banks worldwide, so it was expected they would have such position.

Take in Table III.

Data on Table III show us that the interviewees are not unanimous regarding the existence of the expressions "Knowledge management" and "Intellectual capital" in the bank's documents. Knowledge management and intellectual capital are developing areas and its mentioning in the bank's documents is not yet a rule.

Take in Table IV.

Data on Table IV show us that the interviewees are not unanimous regarding the existence of the expressions "Knowledge management" and "Intellectual capital" in the annual reports of the bank as well. Knowledge management and intellectual capital are developing areas and its reporting is not yet a common practice.

Table $\mathrm{V}$ presents the information on the perceptions of Knowledge management of the interviewees, collected on a page at the end of the interviews: the perception of the interviewees regarding documents, the percentage of the results of the bank due to knowledge management and attributing 100 points between two different knowledge management strategies.

Take in Table V.

Data on Table V show us that according to the interviewees all the banks participating in the study do not have periodic reports on Knowledge management, or annual 
documents on Knowledge management. The banks results attributed by the interviewees due to its Knowledge management are on average 34\%. This value represents over a third of the results of the banks, and that, according to the interviewees, is considered to be due to Knowledge management. Regarding the two different Knowledge management strategies considered; "Innovate and create new knowledge" (corresponding to the Exploration) and "Leverage and distribute knowledge" (corresponding to the Exploitation), the interviewees, on average, valuated more the later $(56 \%)$ than the former $(44 \%)$. It is acceptable to interpret this to be a sign of the predominance of the Exploitation knowledge management strategy in the banks. This result is consistent with the following data analysis.

Take in Table VI.

Data on Table VI show us that the interviewees are not unanimous regarding the existence of experimentation in the bank, according to the interviewees; in the majority of the banks they testify the implementation of new ideas, and all the interviewees declare there is support to knowledge diffusion in the bank.

Regarding the two different Knowledge management strategies considered in this study it can be associated: "Experimentation" and "New ideas implementation" to the Exploration knowledge management strategy and "Knowledge diffusion" to the Exploitation knowledge management strategy. It is possible to verify that interviewees from bank 6 and bank 9 do not recognise the existence of the implementation of new ideas, nor the support to knowledge diffusion in the bank. On the contrary, all the interviewees recognise the existence of support to knowledge diffusion in the bank. It is acceptable to interpret this to be a sign of the predominance of the Exploitation knowledge management strategy in the banks.

Take in Table VII.

Table VII aggregates the information from Tables V and VI. Data on Table VII show us that the interviewees are consistent over the interview. The average valuation given to the perception of the two different Knowledge management strategies considered are consistent with the recognition of certain knowledge management activities in the bank identified by the interviewees:

They recognise the existence of such organizational characteristics (experimentation and new ideas implementation) strongly associated to the Exploration knowledge management strategy (innovation and creation of new knowledge) in $61 \%$ of their answers.

On the other hand they recognise the existence of such an organizational characteristic (knowledge diffusion) strongly associated to the Exploitation knowledge management strategy (leverage and distributing new knowledge) in 100\% of their answers.

This seams to be validated by the valuation previously attributed when identifying perceptions of knowledge management, associated to the two different Knowledge management strategies considered:

Regarding "Innovate and create new knowledge" (corresponding to the Exploration) the interviewees, on average, percept its existence in $44 \%$ of cases.

Regarding "Leverage and distribute knowledge" (corresponding to the Exploitation), the interviewees, on average, percept its existence in $56 \%$. 
Table VIII presents the information on the perceptions of Intellectual capital of the interviewees, collected on a page at the end of the interviews: the perception of the interviewees regarding documents, the percentage of the results of the bank due to knowledge management and attributing 100 points between the three different intellectual capital components.

Take in Table VIII.

Data on Table VIII show us that according to the interviewees on the majority of the banks participating in the study there are no periodic reports on Intellectual capital, nor annual documents on Intellectual capital. The value of the banks due to its Intellectual capital attributed by the interviewees is on average $55 \%$. This value represents over half of the value of the banks, and that, according to the interviewees, is considered to be due to Intellectual capital. Regarding the three different Intellectual capital components considered; people, internal structures and external structures, the interviewees, on average, valuated more people over the other two. This result is consistent with two previous works done in Ireland in the technological sector (telecom, media and software):

In 1999-2000 O'Donnell and other authors (O'Donnell et al., 2001) gathered in a similar way the perceptions of Intellectual capital of CEO's of Irish capital organizations with 40 employees or over: On average, the value of the organizations due to its Intellectual capital was $64 \%$. Regarding the three different Intellectual capital components considered, on average, they were valued as follows; people $-47 \%$, internal structures - $21 \%$ and external structures $-32 \%$.

In 2001 O'Regan and other authors (O'Regan et al., 2002) gathered in a similar way the perceptions of Intellectual capital of CEO's of Irish or foreign capital organizations with 10 employees or over: On average, the value of the organizations due to its Intellectual capital was 59\%. Regarding the three different Intellectual capital components considered, on average, they were valued as follows; people $-55 \%$, internal structures $22 \%$ and external structures $-23 \%$.

In this research the author has reached very similar values to previous studies. Regarding the Value of organization (\%) due to IC - +/- 55\% on average - the author found these results very disturbing following O'Donnell et al., 2001 and O'Regan et al., 2002, as these results contrast with the inexistence of a CKO, or other position fully dedicated to the intellectual capital management of the bank.

Although this study (as well as the previous ones) has collected evidence in support of the highly valuation Intellectual capital is given by top managers, the author is aware that most of Intellectual capital is embedded in intangible assets that, in most cases, are not recognised in the traditional accountancy paradigm in use.

\section{Results from the interviews' content analysis and discussion}

\section{a) Knowledge management}

From the content analysis of the interviews, and regarding knowledge management, it was possible to verify that the expression "knowledge management" is widely known by the interviewees and generally associated to very positive attributes and also related to people in the organization, their capabilities, competences and knowledge. There is also a valuation of aspects regarding the future, like recruitment, potential, training and 
development. The examples of knowledge management presented by the interviewees gather components mainly related to the structure of the bank, like information, diffusion channels, registration routines and internal systems, as well as aspects related to human resources, like people, training and teams.

Regarding the perspective interviewees have on what the banks consider to be "knowledge management" it is something related to training, strategic management and people's knowledge. The perception of the interviewees on what the banks consider to be knowledge management is consistent with the daily examples of knowledge management given by them, especially when they mention training and strategic thinking. The perception of the interviewees on what the banks consider to be knowledge management seams to be very well reflected in the daily examples of knowledge management given by the interviewees.

The majority of the interviewees have declared that there is no position at the bank fully dedicated to knowledge management. Regarding the existence of the expression "knowledge management" in the bank's documents the interviewees have declared that to happen more often than the existence of knowledge management reports on the banks. It is acceptable to conclude that knowledge management is a developing area and reporting is not yet a common practice.

Regarding the existence of a knowledge management strategy at the banks the interviewees weren't unanimous: some declared there is none; some others identified an existing knowledge management strategy, presenting characteristics associated to Exploitation knowledge management strategy. Regarding the existence of knowledge retaining practices at the banks, interviewees were able to present several examples and among them culture.

The qualitative content analysis of the interviews allowed us to verify empirically most of the theoretical knowledge management literature, like:

Knowledge is a complex concept and it only exists in organizations in a very abstract way (Lahti and Moilanen, 2004): “... it is a concept too abstract, with no real concrete actions, too abstract, too theoretical yet..." (Bank 8) “... knowledge management, first let me tell you that I find it a very academic word" (Bank 2).

We can consider that knowledge management is still in its adolescence (Despres and Chauvel, 2002): “... if we could repeat this interview by the end of the year, and according to my planning, instead of telling you that I'm waiting for approval, I hope I would be able to describe to you concrete situations, because according to the $200 \mathrm{X}$ plan by then some projects would be operating. As far as now they are just proposals..." (Bank 8); (a knowledge management strategy) "It is not formalized it is just in my plan of activities" (Bank 8); “... that's one of those new concepts, isn't it?” (Bank 3).

\section{b) Intellectual capital}

From the content analysis of the interviews, and regarding intellectual capital, the author was able to verify that the expression "intellectual capital" is widely known by the interviewees and generally associated to very positive attributes and also related to characteristics involving people in the organization, like knowledge, capabilities and competence. There is also a valuation of innovation aspects regarding intellectual capital, as well as the necessity to retain knowledge and people at the organization. The examples of knowledge management presented by the interviewees gather components mainly related to the human resources of the bank, like knowledge management, people 
and capabilities, and demonstrate huge valuation of the human factor at the organization.

Regarding the perspective interviewees have on what the banks consider to be "intellectual capital" it is something complex, as it involves at the same time the organization's interior (knowledge; people) and the organization's exterior (clients), and it is consider to be mobile, new and abstract. The perception of the interviewees on what the banks consider to be intellectual capital is consistent with the daily examples of intellectual capital given by the interviewees.

The majority of the interviewees have declared that there is no position at the bank fully dedicated to intellectual capital management. Regarding the existence of the expression "intellectual capital" in the bank's documents and the existence of intellectual capital reports on the banks, they are no longer a minority. It is acceptable to conclude that intellectual capital is a developing area and reporting is an emerging practice.

Regarding the existence of an intellectual capital strategy at the banks several interviewees have declared that there was none, and one interviewee identified its existence, although not yet formalized. Another interviewee stated that the strategy was being defined at the moment and yet another one has declared that the formalization has already been done and that the final proposal was under appreciation at the time. Only one interviewee has declared such a strategy exists in the bank. This seams to indicate that organizations are awakening to the process of intellectual capital strategy formalization.

Regarding the existence of intellectual capital retaining practices at the banks, interviewees were able to present several examples; they mentioned individual aspects as well as the concept of value creation in the retention of intellectual capital in the organization.

The qualitative content analysis of the interviews allowed us to verify empirically most of the theoretical intellectual capital literature, like:

Human capital guarantees the inputs to the knowledge creation process (Boisot, 2002). Diffusing and leveraging human capital within the organization helps the firm to do its work (Hitt et al., 2001a). External structure or relational capital consists of the value of continued relations with loyal and satisfied clients (Sveiby, 1997). External structure or relational capital represents the potential an organization has got due to its external relationships. This component gathers intangible elements such as knowledge of clients (Bontis, 2002d). Relational capital is the one involved in the net of the organization's external relationships. This intellectual capital's component is mainly tacit and it is embedded in the long term relations established with clients (Sánchez et al., 2000).

The author was able to find some very interesting declarations in support of the literature review:

Knowledge in organizations is a confused and difficult to measure concept (Spender, 2002; Soo et al., 2002): “... I would say that it has to be operational” (Bank 6); “... something that I could measure more easily, let's say so, and that I could look at it like I look at other the other capitals... so, if I could measure the value of intellectual capital, and I do think it should be possible, I would look at it the way I look at the other capitals" (Bank 4).

Contrary to some literature, knowledge management and intellectual capital are not the same. There is an overlap, but the relationship between the two is far from being simple (Ariely, 2003): "Well... it is pretty much the same, knowledge management and intellectual capital, isn't it?" (Bank 1); “I must tell you that I often can't distinguish 
them" (Bank 5); "We are talking about the same, knowledge management and intellectual capital, yes?” (Bank 9).

\section{Conclusions and limitations}

The qualitative data on our study confirmed much of the literature review. The author thinks this paper does contribute to our knowledge of the phenomenon at hand in different ways:

Firstly, the paper presented the opportunity to empirically verify in the segment studied (banks operating in Portugal with over 50 branches) the relevancy of the themes: knowledge management and intellectual capital, specifically by; the number of banks participating in the study ( $82 \%$ of the segment) and the top management level interviews the author was allowed to develop.

Secondly, the paper reflects that the knowledge management strategy most valuated in the banks is similar to an Exploitation knowledge management strategy - leveraging knowledge; distributing knowledge and diffusing knowledge. Opposite to a less valuated knowledge management strategy in the banks similar to an Exploration knowledge management strategy - innovate and create new knowledge, experimentation and new ideas implementation.

On the other hand, banks keep on presenting new products at a very fast pace and that is why banks have such an innovative image. According to data collected in this study, the author concluded that the innovative image banks present to customers doesn't rule in the knowledge management strategy of the bank. Apparently innovation is strictly allowed in the commercial department.

Thirdly, the results emerging from the paper are consisting with previous studies, the most valued intellectual capital component is human capital (related to people, associated to the amount of knowledge that doesn't remain in the organization when the individuals go out and generally in its tacit form). According to the interviewees, on average, this intellectual capital component alone accounts for half of the total value to intellectual capital in the bank. According to the interviewees, on average 55\% of the value of the bank is due to its intellectual capital, so the paper allows to conclude that the banks consider half of that value (around 27,5\%) to be due to something that is highly volatile that easily walks out the door - human capital.

The author also found out that, consisting with previous studies, that there is a less valuation of the other two intellectual capital components: internal structures and external structures (these are made of the tacit and explicit knowledge that is contained in documents, routines, organizational culture and the net of the organization's external relationships embedded in the long term relations established with clients, suppliers, authorities and other institutions) which remains in the organization after the individuals have left.

As a final comment the author alerts banks for the risk they are exposed to, and warn them to try to convert human capital into the more permanent intellectual capital components: internal structures and external structures.

Fourthly, the paper presented the opportunity to verify that the value given to knowledge management and intellectual capital in the banks is consistent with the relevancy of the knowledge management and intellectual capital literatures and the necessity to develop knowledge management and intellectual capital reporting as a common practice. 
According to the interviewees, on average 34\% of bank results are due to knowledge management, but there is no knowledge manager, or Chief Knowledge Manager (CKO) in any of the structures of the banks participating in the study. The recognised contribution of knowledge management to the bank's results doesn't match the inexistence of knowledge management reports in the banks.

According to the interviewees, on average $55 \%$ of the value of the bank is due to its intellectual capital, but there is no intellectual capital manager in any of the structures of the banks participating in the study. The recognised contribution of intellectual capital to the bank's value doesn't match the inexistence of intellectual capital reports in the banks.

Finally, the author considers this study to be a further step in the scholarly research concerning knowledge management and intellectual capital in the banking industry. Knowledge management and intellectual capital are research fields that still face some lack of cumulative theoretical development and empirical studies, presenting challenging and interesting opportunities to explore these concepts and their perceptions at the organizations. Following the literature, the banking industry proved to be an excellent setting for the study, both in terms of firm's participation and the relevancy of the research questions involved. The implications of this study in terms of knowledge management strategy identification and intellectual capital components valuation hopefully will conduct to more academic research.

However, several limitations associated with the present empirical approach to organizations should be noticed; the reduced number of banks involved (nine) and the reduced number of interviewees per bank (one). Regarding the concepts addressed some limitations may apply considering the definitions of knowledge management and intellectual capital followed. In that sense, future work could make a valid contribution following definitions by other authors. This study didn't address the effects of contextual variables that might have an influence, and so the debate is turned on allowing for new developments. In that sense, there are some research limitations regarding the industry context, but this may result in a stimulus for the replication of the work in other industries.

\section{REFERENCES}

Alvarez S. and Barney J. (2001), How entrepreneurial firms can benefit from alliances with large partners, Academy of Management Executive, 15 (1), 139-148.

Alvarez S. and Busenitz L. (2001), The entrepreneurship of resource-based theory, Journal of Management, 27, 755-775.

Ariely G. (2003), Knowledge Management As A Methodology Towards Intellectual Capital. Article presented at the $3{ }^{\text {rd }}$ European Knowledge Management Summer School, Spain, September 7 - 12, San Sebastian.

Barney J. (1991), Firm Resources and Sustained Competitive Advantage, Journal of Management, 17 (1), 99-120.

Barney J. (2001), Resource-based theories of competitive advantage: A ten-year retrospective on the resource-based view, Journal of Management, 27, 643-650.

Bart C. (2001), Measuring the mission effect in human intellectual capital, Journal of Intellectual Capital, 2 (3), 320-330.

Bierly P. and Daly P. (2002), "Aligning Human Resource Management Practices and Knowledge Strategies: A Theoretical Framework", Choo C. and Bontis N., The 
Strategic Management of Intellectual Capital and Organizational Knowledge, Oxford University Press, New York, 277-295.

Birchall, D. and Tovstiga, G. (1999), The Strategic Potential of a Firm's Knowledge Portfolio, Journal of General Management, 25 (1), 1-16.

Blackler F. (2002), "Knowledge, Knowledge Work, and Organizations: An Overview and Interpretation", Choo C. and Bontis N., The Strategic Management of Intellectual Capital and Organizational Knowledge, Oxford University Press, New York, , 47- 64.

Bontis N. (1998), Intellectual Capital: an exploratory study that develops measures and models, Management Decision, 36 (2), 63-76.

Bontis N. (2002a), The rising star of the Chief Knowledge Officer, Ivey Business Journal, March/April, 20-25.

Bontis N. (2002b), Intellectual Capital Disclosure in Canadian Corporations, Journal of Human Costing \& Accounting, 7, 9-20.

Bontis N. (2002c), National Intellectual Capital Index: Intellectual Capital Development in the Arab Region, Jan.-10-2002, United Nations Office for Project Services. www.bontis.com

Bontis N. and Nikitopoulos D. (2001), Thought leadership on intellectual capital, Journal of Intellectual Capital, 2 (3), 183-191.

Bontis N., Crossan M. and Hulland J. (2002), Managing Organizational Learning Systems by Aligning Stocks and Flows, Journal of Management Studies, 39 (4), 437469.

Bontis N. and Fitz-Enz J. (2002), Intellectual Capital ROI: A causal map of human capital antecedents and consequents, Journal of Intellectual Capital, 3 (3), 223-247.

Bowen J. and Ford R. (2002), Managing Service Organizations: Does Having a "Thing" Make a Difference?, Journal of Management, 26 (3), 447-469.

Brooking A. (1997), The Management of Intellectual Capital, Long Range Planning, 30 (3), 364-365.

Buckley P. and Carter M. (2000), Knowledge Management in Global Technology Markets, Long Range Planning, 33, 55-71.

Caddy I., Guthrie J. and Petty R. (2001), Managing orphan knowledge: current Australasian best practice, Journal of Intellectual Capital, 2 (4), 384-397.

Canibano L., García-Ayuso M, Sánchez P. and Olea M. (1999), Measuring intangibles to understand and improve innovation management. Preliminary results. Article presented at the OECD International Symposium Measuring and Reporting Intellectual Capital: Experience, Issues and Prospects, June 9 - 11, Amsterdam.

Choo C. (2002), "Sensemaking, Knowledge Creation, and Decision Making", Choo C. and Bontis N., The Strategic Management of Intellectual Capital and Organizational Knowledge, Oxford University Press, New York, 79-88.

Choo C. and Bontis, N. (2002) "Knowledge, Intellectual Capital, and Strategy: Themes and Tensions", Choo C. and Bontis N., The Strategic Management of Intellectual Capital and Organizational Knowledge, Oxford University Press, New York, 3-19.

Choo C. and Bontis N. (2002), The Strategic Management of Intellectual Capital and Organizational Knowledge, Oxford University Press, New York.

Cohen W. and Levinthal D. (1990), Absorptive Capacity: A New Perspective on Learning and Innovation, Administrative Science Quarterly, 35 (1), 128-152.

Cohen D. and Pruzac L. (2001), In Good Company: How Social Capital Makes Organizations Work, Harvard Business Scholl Press, Boston. 
Crossan M. and Hulland J. (2002), "Leveraging Knowledge through Leadership of Organizational Learning", Choo C. and Bontis N., The Strategic Management of Intellectual Capital and Organizational Knowledge, Oxford University Press, New York, 711-723.

Davenport, T. and Pruzac, L. (2000), Working Knowledge: How Organizations Manage What They Know, Harvard Business Scholl Press, Boston.

De Carolis D. (2002), "The Role of Social Capital and Organizational Knowledge in Enhacing Entrepreneurial Opportunities in High-Technology Environments", Choo C. and Bontis N., The Strategic Management of Intellectual Capital and Organizational Knowledge, Oxford University Press, New York, 699-709.

Despres C. and Chauvel D. (2002), "Knowledge, Context and the Management of Variation", Choo C. and Bontis N., The Strategic Management of Intellectual Capital and Organizational Knowledge, Oxford University Press, New York, 89-99.

Dess G., Gupta A., Hennart J. and Hill C. (1995), Conducting and Integrating Strategy Research at the International, Corporate, and Business Levels: Issues and Directions, Journal of Management, 21 (3), 357-393.

Dierickx I. and Cool K. (1989), Asset stock accumulation and sustainability of competitive advantage, Management Science, 35 (12), 1504-1511.

Doty D., Glick W. and Huber G. (1993), Fit, Equifinality, and Organizational Effectiveness: a test of two configurational theories, Academy of Management Journal, 36 (6), 1196-1250.

Drucker P. (1993), Post-Capitalist Society, HarperCollins, New York.

Edvinsson L. (2000), Some perspectives on intangible and intellectual capital 2000, Journal of Intellectual Capital, 1 (1), 12-16.

Garud R. and Kumaraswamy A. (2002), "Technological and Organizational Designs for Realizing Economies of Substitution", Choo C. and Bontis N., The Strategic Management of Intellectual Capital and Organizational Knowledge, Oxford University Press, New York, 233-253.

Glick W., Huber G., Miller C., Doty D. and Sutcliffe K. (1990), Studying changes in organizational design and effectiveness: Retrospective even histories and periodic assessments, Organizational Science, 1, 293-312.

Gratton L. and Ghoshal S. (2003), Managing Personal Human Capital: New Ethos for the 'Volunteer' Employee', European Management Journal, 21 (1), 1-10.

Guthrie J. (2001), The management, measurement and the reporting of intellectual capital, Journal of Intellectual Capital, 2 (1), 27-41.

Hambrick D. (1981), Strategic Awareness Within Top Management Teams, Strategic Management Journal, 2, 263-279.

Hitt M., Bierman L., Shimizu K. and Kockhar R. (2001a), Direct and moderate effects of human capital on strategy and performance in professional service firms: a resourcebased perspective, Academy of Management Review, 44 (1), 13-28.

Hooff B., Vijvers J. and Ridder J. (2003), Foundations and Applications of a Knowledge Management Scan, European Management Journal, 21 (2), 237-246.

Huizing, A. and Bouman, W. (2002), "Knowledge and Learning Markets and Organizations", Choo C. and Bontis N., The Strategic Management of Intellectual Capital and Organizational Knowledge, Oxford University Press, New York, 185-204.

Ichijo K. (2002), "Knowledge Exploitation and Knowledge Exploration: Two Strategies for Knowledge Creating Companies", Choo C. and Bontis N., The Strategic 
Management of Intellectual Capital and Organizational Knowledge, Oxford University Press, New York, 477-483.

Ireland D., Hitt M., Bettis R . and Auld de Porras D. (1987), Strategy formulation processes: Differences in perceptions of strengths and weaknesses indicators and environmental uncertainty by managerial level, Strategic Management Journal, 8, 469485.

Joia L. (2000), Measuring intangible corporate assets, Journal of Intellectual Capital, 1 (1), 68-84.

Knott A. (2002), "Exploration and Exploitation as Complements", Choo C. and Bontis N., The Strategic Management of Intellectual Capital and Organizational Knowledge, Oxford University Press, New York, 339-358.

Lahti S. and Moilanen R. (2004), Sharing of the tacit knowledge - a challenge of managing young and aging employees. Article presented at the $19^{\text {th }}$ Workshop on Strategic Human Resource Management, HEC-PARIS, April 22 - 23.

Lovas B. and Ghoshal S. (2000), Strategy as Guided Evolution, Strategic Management Journal, 21, 875-896.

Lynn B. (1998), Intellectual Capital: 'Key to value-added success in the next millennium', CMA Magazine, Feb. 1998, 10-15.

March J. (1991), Exploration and Exploitation in organizational learning, Organization Science, 2, 71-87.

McElroy M. (2002), Social innovation capital, Journal of Intellectual Capital, 3 (1), 3039.

McEvily S. and Chakravarthy B. (2002), The persistence of Knowledge-based Advantage: an Empirical Test for Product Performance and Technological Knowledge, Strategic Management Journal, 23, 285-305.

Mehra A. (1996), Resource and market based determinants of performance in the U.S. banking industry, Strategic Management Journal, 17 (4), 307-322.

Mouritsen J., Larsen H., Bukh P. and Johansen M. (2001), Reading an intellectual capital statement - Describing and prescribing knowledge management strategies, Journal of Intellectual Capital, 2 (2), 359-383.

Nahapiet J. and Ghoshal S. (2002), "Social Capital, Intellectual Capital, and the Organizational Advantage", Choo C. and Bontis N., The Strategic Management of Intellectual Capital and Organizational Knowledge, Oxford University Press, New York, 673-697.

Nonaka I. (1991), The Knowledge-Creating Company, Harvard Business Review, November-December, 96-104.

Nonaka I. and Konno, N. (1998), The Concept of "Ba": Building a Foundation for Knowledge Creation, California Management Review, 40 (3), 40-54.

Nonaka I., Toyama R. and Nagata A. (2000b), A Firm as a Knowledge-creating Entity: A New Perspective on the Theory of the Firm, Industrial and Corporate Change, 9 (1), $1-20$.

O’Donnel D., O’Regan P. Coates B., Kennnedy T., Kearly B. and Berkery G. (2001), Human interaction: the critical source of value in the intellectual age, Proccedings of the $4^{\text {th }}$ World Congress on Intellectual Capital, Hamilton, Ontario, Canada, January. 17-19.

O'Regan P., O’Donnell D., Kennedy T., Bontis N. and Cleary P. (2002), Perceptions of Intellectual Capital: Irish Evidence, Journal of Human Resource Costing \& Accounting, $6(2), 29-38$. 
Petrash G. (1996), Dow's Journey to a Knowledge Value Management Culture, European Management Journal, 14 (4), 365-373.

Pike S., Rylander A. and Roos G. (2002), "Intellectual Capital Management and Disclosure", Choo C. and Bontis N., The Strategic Management of Intellectual Capital and Organizational Knowledge, Oxford University Press, New York, 657-671.

Polanyi M. (1962), Personal Knowledge: Toward a Post-critical Philosophy, University of Chicago Press, Chicago.

Roberts B. (2000), Pick Employees' Brains, HR Magazine, Feb., 115-120.

Roberts P. and Amit, R. (2003), The Dynamics of Innovative Activity and Competitive Advantage: The case of Australian Retail Banking, 1981 to 1995, Organization Science, 14 (2), 107-122.

Rouse, M. and Daellenbach, U. (2002), More Thinking on Research Methods for the Resource-Based Perspective, Strategic Management Journal, 23, 963-967.

Saint-Onge H. (1996), Tacit knowledge: The key to the strategic alignment of intellectual capital, Strategy \& Leadership, 24 (2), 10-14.

Sánchez P., Chaminade C. and Olea M. (2000), Management of Intangibles an attempt to build a theory, Journal of Intellectual Capital, 1 (4), 312-327.

Soo C., Devinney T., Midgley D. and Deering A. (2002), Knowledge Management: Philosophy, Processes and Pitfalls, California Management Review, 44 (4), 129-150.

Spender J. (2002), "Knowledge, Uncertainty and an Emergency Theory of the Firm", Choo C. and Bontis N., The Strategic Management of Intellectual Capital and Organizational Knowledge, Oxford University Press, New York,., 149-162.

Starbuck W. (2002), "Keeping a Butterfly and an Elephant in a House of Cards", Choo C. and Bontis N., The Strategic Management of Intellectual Capital and Organizational Knowledge, Oxford University Press, New York, 371-401.

Stewart T. (1997), Intellectual Capital: The New Wealth of Organizations, Doublebay, New York: NY.

Stewart T. (1998), Knowledge, the Appreciating Commodity, Fortune, October, 199200.

Stovel, M. and Bontis, N. (2002), Voluntary Turnover: Knowledge Management Friend or Foe, Journal of Intellectual Capital, 3 (3), 303-322.

SubbaNarasimha, P. (2001), Salience of knowledge in a strategic theory of the firm, Journal of Intellectual Capital, 2 (3), 215-224.

Sveiby K. (1996), Transfer of Knowledge and the Information Processing Professions, European Management Journal, 14 (4), 379-388.

Sveiby K. (1997), The New Organizational Wealth, Berrett-Koehler Publishers, San Franscisco.

Sveiby K. (2001b), A knowledge-based theory of the firm to guide in strategy formulation, Journal of Intellectual Capital, 2 (4), 334-358.

Szulanski G. (2003), Sticky Knowledge - barriers to knowing in the firm, Sage Publicatios Ltd, London.

Teece D., Pisano G. and Shuen A. (1997), Dynamic capabilities and strategic management, Strategic Management Journal, 18 (7), 509-534.

Teece D. (1998), Capturing value from knowledge assets: the new economy, markets for know-how and intangible assets, California Management Review, 40 (3), 55-79.

Wernerfelt B. (1984), A resource-based view of the firm, Strategic Management Journal, 5 (2), 171-180. 
Wexler M. (2002), Organizational memory and intellectual capital, Journal of Intellectual Capital, 3 (4), 393-414.

Wiig K. (1997), Integrating Intellectual Capital and Knowledge Management, Long Range Planning, 30 (3), 399-405.

Winter, S. and Szulanski, G. (2002), "Replication of Organizational Routines: Conceptualizing the Exploitation of Knowledge Assets", Choo C. and Bontis N., The Strategic Management of Intellectual Capital and Organizational Knowledge, Oxford University Press, New York, 207-221.

Zack M. (2002), "Developing a Knowledge Strategy", Choo C. and Bontis N., The Strategic Management of Intellectual Capital and Organizational Knowledge, Oxford University Press, New York, 255-276.

Zajac R. and Wolfe D. (1966), Cognitive consequences of a person's position in a formal organization, Human Relations, 19, 139-150. 
Table I. Data on the interviewee, the institution and the interview.

\begin{tabular}{|c|c|c|c|c|c|c|c|}
\hline Bank & Sex & Age & Position & $\begin{array}{l}\mathrm{N}^{\mathrm{o}} \text { of } \\
\text { years in } \\
\text { position }\end{array}$ & $\begin{array}{l}\mathrm{N}^{0} \text { of years } \\
\text { in the } \\
\text { institution }\end{array}$ & $\begin{array}{l}\mathrm{N}^{\mathrm{o}} \text { of years } \\
\text { of the } \\
\text { institution }\end{array}$ & $\begin{array}{l}\text { Interview } \\
(\mathrm{min})\end{array}$ \\
\hline 1 & M & 40 & HR Sub-Dir. & 3 & 6 & 10 & 54,4 \\
\hline 2 & M & 42 & HR Dir. & 4 & 13 & 23 & 49,2 \\
\hline 3 & $\mathrm{~F}$ & 46 & HR Dir. & 6 & 1 & 10 & 43,8 \\
\hline 4 & M & 54 & HR Expert & 18 & 30 & 120 & 54,8 \\
\hline 5 & $\mathrm{~F}$ & 44 & HR Dir. & 1 & 22 & 148 & 45,0 \\
\hline 6 & M & 50 & HR Dir. & 7 & 14 & 19 & 49,8 \\
\hline 7 & M & 48 & HR Sub-Dir. & 8 & 25 & 127 & 76,4 \\
\hline 8 & M & 31 & HR Sub-Dir. & 0 & 0 & 17 & 48,4 \\
\hline 9 & $\mathrm{M}$ & 45 & HR Dir. & 6 & 14 & 165 & 73,0 \\
\hline Average & & 44 & & 6 & 14 & 71 & 55,0 \\
\hline
\end{tabular}


Table II. Position's inventory.

\begin{tabular}{llll}
\hline Bank & $\begin{array}{l}\text { Position for Knowledge } \\
\text { management }\end{array}$ & $\begin{array}{l}\text { Position for Intellectual } \\
\text { capital management }\end{array}$ & $\begin{array}{l}\text { CKO - Chief Knowledge } \\
\text { Officer }\end{array}$ \\
1 & $\begin{array}{l}\text { Not as a especial } \\
\text { attribution }\end{array}$ & No & No \\
2 & No & No & No \\
3 & No & No & No \\
4 & Yes & Probably yes & No \\
5 & No & No & No \\
6 & No, not yet & No & No \\
7 & No & No & No \\
8 & Yes & Yes & No \\
9 & No & No & No \\
\hline
\end{tabular}


Table III. Expressions in the bank's documents.

\begin{tabular}{lll}
\hline Bank & $\begin{array}{l}\text { "Knowledge management" } \\
\text { in the bank's documents }\end{array}$ & $\begin{array}{l}\text { "Intellectual capital" } \\
\text { in the bank's documents }\end{array}$ \\
1 & No & Yes \\
2 & Yes & Yes \\
3 & No & No \\
4 & Not that I recall & Yes \\
5 & Yes & Yes \\
6 & Yes & Yes \\
7 & Yes, plenty at this moment & No \\
8 & I don't think so & No \\
9 & No & No \\
\hline
\end{tabular}


Table IV. Annual reports of the bank.

\begin{tabular}{lll}
\hline Grupo & $\begin{array}{l}\text { References on "Knowledge management" } \\
\text { at the annual reports of the bank }\end{array}$ & $\begin{array}{l}\text { References on "Intellectual capital" at } \\
\text { the annual reports of the bank }\end{array}$ \\
1 & No & Yes \\
2 & No & No \\
3 & No & Yes \\
4 & Yes & Yes \\
5 & I don't know & Yes \\
6 & No & \\
7 & There are only certain areas to report & No \\
& developed training activities & No \\
9 & No & No \\
\hline
\end{tabular}


Table V. Perceptions of Knowledge management.

\begin{tabular}{|c|c|c|c|c|c|}
\hline Bank & $\begin{array}{l}\text { Periodic } \\
\text { reports } \\
\text { on KM }\end{array}$ & $\begin{array}{l}\text { Annual } \\
\text { documents } \\
\text { on KM }\end{array}$ & $\begin{array}{l}\text { (\%) Bank Results } \\
\text { due to KM }\end{array}$ & $\begin{array}{l}\text { Innovate and } \\
\text { create new } \\
\text { knowledge }\end{array}$ & $\begin{array}{l}\text { Leverage and } \\
\text { distribute } \\
\text { knowledge }\end{array}$ \\
\hline 1 & No & No & 40 & 20 & 80 \\
\hline 2 & No & No & $? ? ?$ & 70 & 30 \\
\hline 3 & No & No & 20 & 70 & 30 \\
\hline 4 & No & No & 40 & 30 & 70 \\
\hline 5 & No & No & 80 & 60 & 40 \\
\hline 6 & No & No & 15 & 30 & 70 \\
\hline 7 & No & No & $? ? ?$ & 40 & 60 \\
\hline 8 & No & No & 10 & 50 & 50 \\
\hline 9 & No & No & 35 & 30 & 70 \\
\hline Average & & & 34 & 44 & 56 \\
\hline
\end{tabular}

$\mathrm{KM}$ - Knowledge management.

??? - The interviewee was not able to answer. 
Table VI. Experimentation, new ideas implementation and knowledge diffusion.

\begin{tabular}{llll}
\hline Bank & Experimentation & $\begin{array}{l}\text { New ideas } \\
\text { implementation }\end{array}$ & $\begin{array}{l}\text { Knowledge } \\
\text { diffusion } \\
\text { No }\end{array}$ \\
1 & Yes & Yes & Yes \\
2 & Yes & Yes & Yes \\
3 & Yes & Yes & Yes \\
4 & Yes & Yes & Yes \\
5 & No & No & Yes \\
6 & No & Yes & Yes \\
7 & No & Yes & Yes \\
8 & Yes & No & Yes \\
9 & No & & \\
\hline
\end{tabular}


Table VII. Perception vs Recognition of Knowledge management.

\begin{tabular}{|c|c|c|c|c|c|c|}
\hline Interviewee & $\begin{array}{l}\text { Innovate } \\
\text { create } \\
\text { knowledge }\end{array}$ & $\begin{array}{l}\text { and } \\
\text { new }\end{array}$ & $\begin{array}{l}\text { Leverage and } \\
\text { distribute } \\
\text { knowledge }\end{array}$ & $\begin{array}{l}\text { Experimentation } \\
+ \text { New ideas } \\
\text { implementation }\end{array}$ & $\begin{array}{l}\text { Knowledge } \\
\text { diffusion }\end{array}$ & \\
\hline Average & & 44 & 56 & $\begin{array}{r}61 \% \\
(11 / 18) \\
\end{array}$ & & $\begin{array}{r}100 \% \\
(9 / 9) \\
\end{array}$ \\
\hline
\end{tabular}


Table VIII. Perceptions of Intellectual capital.

\begin{tabular}{|c|c|c|c|c|c|c|}
\hline Bank & $\begin{array}{l}\text { Periodic } \\
\text { reports on } \\
\text { IC }\end{array}$ & $\begin{array}{l}\text { Annual } \\
\text { documents } \\
\text { on IC }\end{array}$ & $\begin{array}{l}\text { Value of the } \\
\text { Bank }(\%) \text { due } \\
\text { to IC }\end{array}$ & People & $\begin{array}{l}\text { Internal } \\
\text { structure }\end{array}$ & $\begin{array}{l}\text { External } \\
\text { structure }\end{array}$ \\
\hline 1 & Yes (a) & Yes (a) & 70 & 40 & 35 & 25 \\
\hline 2 & No & No & $>50$ & 33,33 & 33,33 & 33,33 \\
\hline 3 & No & No & $\begin{array}{r}\text { between } 15 \\
\text { and } 20\end{array}$ & 50 & 30 & 20 \\
\hline 4 & No & No & 20 & 60 & 30 & 10 \\
\hline 5 & No & $? ? ?$ & 80 & 40 & 30 & 30 \\
\hline 6 & No & No & 80 & 50 & 10 & 40 \\
\hline 7 & No & No & ??? & 60 & 20 & 20 \\
\hline 8 & No & No & 75 & 60 & 15 & 25 \\
\hline 9 & No & No & 50 & 60 & 30 & 10 \\
\hline \multirow[t]{2}{*}{ Average } & & & $\begin{array}{l}\text { between } 55 \\
\text { and } 55,625\end{array}$ & 50,37 & 25,93 & 23,70 \\
\hline & & & & & Sum $=10$ & \\
\hline
\end{tabular}

